conclude that mental health professionals "should be aware of the mistakes of the past".

I would like to point out that comparable mistakes continue in many parts of the world where homosexuality is still pathologised and substantially stigmatised. For example, according to the second revised edition of the Chinese Classification of Mental Disorders published in 1995, homosexuality remains a diagnosable psychiatric disease in China (Lee, 1996). A senior professor argued that this is because there is a lack of either biological or psychological evidence to show that homosexuality is 'absolutely normal' and that some homosexual people do seek medical or psychological help (Young, 1994). However, Lau \& $\mathrm{Ng}$ (1989) maintained that homosexuality not only has a long history but is also common in Chinese society.

In the USA the diagnostic category of 'egodystonic homosexuality' was not deleted from the DSM system until recently (American Psychiatric Association, 1987). It remains to be seen whether China's rapid economic reforms and admittedly more sluggish political liberalisation will lead to the de-pathologisation of homosexuality and the ripening of the Chinese gay community.

American Pupchiatric Aswockation (19e7) Diognostic and Statistical Manual of Mentol Disonders (3rd edn, revised) (DSM-III-R). Washington, DC: APA.

KIn, M. \& Bartlett, A. (1999) British psychiatry and homosexuality. British foumal of Psychiatry 175, 106-113.

Lau, M. P. N Ng, M. L. (I98s) Homosexuality in Chinese culture. Culture, Medicine and Psychiatry, I3. 465-488.

Lee, S. (199) Cultures in psychiatric nosology: the CCMD-2-R and international classification of mental disorders. Culture, Medicine \& Psychiotry 20, 421-472.

Young, $\mathbf{D}$ (1994) A personal view on the publication of the CCMD-2-R (in Chinese). Joumal of Clinical Psychological Medicine, 4, 221-223.

S. Lee Department of Psychiatry, Prince of Wales Hospital, Shatin, Hong Kong

Sir: King \& Bartlett (1999) outline the generally unhappy relationship between British psychiatry and homosexuality. Although British psychiatry never embraced psychoanalysis as in the USA, it still produced its own crop of negative and even homophobic theorising and practice. O'Connor \& Ryan (1993) have mapped out the work to be done for psychoanalytic psychotherapy from a lesbian perspective and I have attempted a smaller-scale exercise for gay men (Ratigan, 1998). We still have a long way to go to match the confidence of the lesbian and gay critiques of both psychiatry and psychoanalysis to be found in the USA (Cabaj \& Stein, 1996).

Working in a specialist National Health Service psychotherapy unit as a psychoanalytic psychotherapist, who happens to be gay, I come across gay men and lesbians who, while being generally content with their sexual orientations, nevertheless have major mental health problems, including personality disorders or perversions. I do not assume that homosexuality is a perversion per se; but there are gays and lesbians and heterosexuals with perversions.

At a recent conference at University College London on 'Narcissism and perversion: modern Kleinian perspectives' none of the clinical material was from the psychotherapies of gay or lesbian patients. It was as if it was not safe publicly to talk about gay or lesbian patients with perverse or narcissistic character structures for fear of being accused of homophobia. This was a pity as it deprives the lesbian and gay communities of current thinking in this area. I could not have imagined such a conference $\mathbf{1 0}$ years ago omitting homosexual material - there would have probably been little else.

Attempts to develop a lesbian and gay affirmative stance in psychotherapy are currently being proposed; it is a liberal not a radical response. Psychoanalysis needs to be challenged to return to its roots and regard all sexualities as problematic. Too much would be lost if we surrendered (the attempt at) therapeutic neutrality in psychoanalytic psychotherapy, especially in work with gay or lesbian patients with major mental health problems.

Cably, R. P. \& stein, T. S. (I9\%) Textbook of Homosexuality and Mental Health. Washington, DC: American Psychiatric Press.

KIng, M. \& Bartlett, A. (1999) British psychiatry and homosexuality. British journal of Psychiatry, 175, 106-113.

O'Connor, N. \& Ryan, J. (1993) Wild Desires and Mistaken Identities: Lesbionism and Psychoonolysis. London: Virago.

Ratigan, B. (1999) Gay men and psychoanalysis: queer bedfellows? In Contemporory Perspectives on Psychotheropy and Homosexualities (ed. C. Shelley). pp. 58-86. London: Free Association Books.

B. Ratigan Nottingham Psychotherapy Unit, St Ann's House, 114 Thorneywood Mount, Nottingham NG3 2PZ

\section{Old age forensic psychiatry}

Sir: The close collaborative working relationship that Gairin \& Quinn (1999) describe between the Yorkshire forensic and old age psychiatry services is interesting and could possibly serve as a model for how services might be organised elsewhere.

The relationship they describe, however, is far from universal and this is precisely the point of my editorial (Yorston, 1999) that psychiatric services for elderly mentally disordered offenders are patchy and uncoordinated with little or no research literature to act as a base for decision-making.

The fact that the number of elderly offenders is small (i.e. there is little demand) should no longer be accepted as a reason for neglecting this group. Whether there is a need for old age forensic psychiatry should be the question that is asked. In my experience, and that of many other old age and forensic psychiatrists, this need clearly exists and is inadequately met in many areas.

The way forward must surely involve more research in this area to determine need, and more debate of the various local solutions that have been found to meet it.

Gairin, L. \& Quinn, P. (1999) Old age forensic psychiatry. British joumal of Psychiotry, 175, 190.

Yorston, C. (1999) Aged and dangerous. Old age forensic psychiatry. British fournal of Psychiatry 174, 193-195.

G. Yorston Udston Hospital, Farm Road, Hamilton ML3 9LA

\section{Serving the interests of the Journol's readers}

Sir: It is genuinely encouraging to see how the Journal is now supporting parallel publication of electronic and paper systematic reviews relating to the care of people with mental health problems (Chalmers, 1999). Other journals have been doing this for a while (Johnstone \& Zolese, 1999; Soares \& McGrath, 1999; Wahlbeck et al, 1999).

We hope this also heralds a sea change in policy regarding treatment reviews in the Joumal. In January-July 1999 the Journal published its randomised trials, all, of course, with a Methods section, encouraging the view that these were as objectively undertaken as possible. Nine of the 15 trials were clearly industry sponsored, which is probably a similar rate to other key joumals. 
Across the same time period the Joumal published 10 reviews of treatment. One of these reviews had a Methods section (Bollini et al, 1999). Seven of the 10 reviews had key authors with clear links to the producers of the drugs that they were reviewing.

The sea change, if it does indeed exist, is welcome.

Bollinl, P., Pampallome, S, THald, G, et of (I9se) Effectiveness of antidepressants. Meta-analysis of doseeffect relationships in randomised dinical trials. British journol of Psychiotry, 174, 297-303.

Chalmers, I. (1999) A symbiosis of paper and electronic publishing, serving the interests of the jouma's readers. British journol of Psychiotry, 175, I-2.
Johnutone, P. Z Zolese, G. (1999) Systematic review of the effectiveness of planned short hospital stays for mental health care. British Medical joumal, 318, $1387-1390$.

Soares, K. V. S. \& McGrath, J. J. (ISw) The treatment of tardive dyskinesia: a systematic review and meta. analysis. Schizophrenio Reseorch, in press.

Whibeck, K., Cheine, M., Eevall, A., of at (19\%9) Evidence of clozapine's effectiveness in schizophrenia: a systematic review and meta-analysis of randomized trials. American joumd of Psychiatry. 156, 990-999.

C. Adams Co-ordinating Editor, Cochrane Schizophrenia Group, University of Oxford. Summertown Pavilion, Middle Way, Summertown, Oxford OX2 $7 \mathrm{LG}$
E da Silva Freire Coutinho Editor, Cochrane Schizophrenia Group. Fundação Oswaldo Cruz, Av. Brasil, 4635-Manguinhos, Rio de Janeiro, Brazil

L. Duggan Comments Editor, Cochrane Schizophrenia Group, St Andrew's Hospital, Billing Road, Northampton NNI 5DG

L. Roberts Administrator/Co-Ordinator, Cochrane Schizophrenia Group. Surnmertown Pavilion, Middle Way, Summertown, Oxford OX2 $7 L G$

K. Wahlbeck Editor, Cochrane Schizophrenia Group, Department of Psychiatry, University of Helsinki, Lappviskgen FIN-00180, Helsinki, Finland

\section{One hundred years ago}

\section{Notes and comment}

A few years since in the State of Kansas for political purposes, a sweeping change was made in the medical officers, attendants and other employees of the State institutions for the insane with the most disastrous results, so disastrous indeed that the politicians who were accountable for the change personally besought at least one of the deposed medical superintendents to resume charge of the institution from which he had been ejected and promised to refrain from interfering with his management in any way if he would only come back and bring order out of the chaos which their meddling had created. There always have been and there always will be men who conceive that it is their duty to change the existing order of things. Some of these by their enthusiasm and by the fact that they are impelled by correct motives have made their mark in the history of the world and have pushed forward the advancing line of civilization. Others who have been governed entirely by selfish motives or even ignorant of the true principles of reform have been clogs in the way.

It after all comes to this, in the words of Herbert Spencer: "There seems no getting people to accept the truth, which nevertheless is conspicuous enough, that the welfare of a society and the justice of its arrangements are at the bottom dependent on the character of its members, and that improve- ment in neither can take place without that improvement in character which results from carrying on peaceful industry under the restraints imposed by an orderly social life. ... The defective natures of citizens will show themselves in the bad acting of whatever social structure they are arranged into. There is no political alchemy by which you can get golden conduct out of leaden instincts."

\section{REFERENCE}

Americon journal of Insanity, LV. July 1899, 172.

Researched by Henry Rollin, Emeritus Consultant Psychiatrist, Horton Hospital, Epsom, Surrey 